\title{
GENETIC STUDIES ON WILD POPULATIONS OF MELANDRIUM
}

\section{CHROMOSOME BEHAVIOUR}

\author{
C. W. LAWRENCE \\ Genetics Department, Birmingham University *
}

Received 27.viii.62

\section{INTRODUCTION}

Azthough mutation is considered to be the origin of heritable variation, the raw material of evolution appears to lie more in new and integrated gene combinations (Fisher, 1930; Goldschmidt, 1940; Mather, 1943; Darlington, 1956a). Emphasis is therefore placed on the mechanisms which control the production of recombinant genotypes ; mechanisms which form part of the genetic system (Darlington, I 939, I958) which Garson (I 956) has called the recombination system. Many of the components of the recombination system are under genetic control, and thus, it was pointed out (Darlington, 1932, 1939, 1958; Mather, 1943), they are susceptible to the action of natural selection. Such selection, it was envisaged, acts indirectly by means of the influence of these characters on the amount of phenotypic variation in the progeny over many generations. In this process the components are mutually adjusted and integrated into a system capable of controlling with great precision the variation exposed to the action of selection.

Experimental evidence supporting this theory is not abundant, and is of two kinds. First, the indirect evidence that components of the system are under genetic control (Chromosome mechanism, Rees, I96r ; Breeding system, Lewis, I954, Breese, I960). Second, direct evidence from the study of wild populations. Evidence of this latter kind is almost exclusively concerned with the occurrence and frequency of chromosome structural rearrangements. In the following account genetic variation between wild populations with regard to the chiasma frequency of male plants is studied in the two closely related species Melandrium album and M. rubrum.

\section{MATERIAL AND METHOD}

The material formed part of a larger experiment to be fully described in the following paper. A random sample of three female and three male plants were taken from each of four wild populations of Melandrium, two of M. album and two of M. rubrum. Plants from the same population were crossed in all possible ways, while those from different populations were crossed in random but independent pairs. The $(4 \times 9)+(6 \times 6)=72$ families which resulted from the crossing were

* Present address : Wantage Research Laboratory (A.E.R.E.) Wantage, Berks. 
planted in 144 plots, each containing ten plants, arranged randomly in one block. For convenience, although with rather loose usage, the four groups of intra-population crosses will be referred to as "parents" and the six groups of inter-population crosses as " $F_{1} s$ ".

For cytological examination buds were taken where possible from four randomly chosen male plants in each plot. The buds were fixed and mordanted in aceticalcohol $(1: 3)$ containing a few drops of ferric chloride solution. Plots of plants were fixed in a random order to avoid bias due to changes in the weather during the period of fixation. After a few weeks in fixative the buds were transferred to 70 per cent. alcohol and stored in a refrigerator. Aceto-carmine squashes were made from the anthers of one bud per plant, and chiasma frequency scored in twenty cells at first metaphase.

Two metrics were determined from the slides (Rees and Thompson, 1956) :-

(i) The average chiasma frequency per plant, expressed as chiasmata per cell.

(ii) The variation in chiasma frequency between cells within plants (the cell variance.

Means and variances were used to summarise the data, rather than giving frequencies of cells with particular numbers of chiasmata, for the sake of convenience. However, with very few exceptions bivalents had either one or two chiasmata, and since the sex bivalent never had more than one, the number of chiasmata per cell ranged in general between 12 and 23. Univalents were rare, less than 0.03 pairs per cell, and in no case were bivalents found with more than two chiasmata. In all 373 plants were examined.

\section{RESULTS}

The average chiasma frequency and cell variance of each group of inter- and intra-population crosses is given in table $I$ and shown

TABLE 1

The average chiasma frequency, expressed as chiasmata per cell (top number) and the average cell variance (bottom number) of each $F_{1}$ and parental group

\begin{tabular}{|c|c|c|c|c|}
\hline & $\mathrm{w}_{7}$ & W8 & $\mathrm{R}_{4}$ & $\mathrm{R}_{5}$ \\
\hline $\mathrm{w}_{7}$ & $\begin{array}{r}13.56 \\
1 \cdot 37\end{array}$ & $\begin{array}{r}14.27 \\
1.63\end{array}$ & $\begin{array}{r}14.75 \\
1.66\end{array}$ & $\begin{array}{r}13.43 \\
1.46\end{array}$ \\
\hline w8 & $\begin{array}{r}14.24 \\
1.65\end{array}$ & $\begin{array}{r}13.85 \\
2.09\end{array}$ & $\begin{array}{r}14 \cdot 36 \\
1 \cdot 77\end{array}$ & $\begin{array}{r}14 \cdot 56 \\
2 \cdot 15\end{array}$ \\
\hline $\mathrm{R}_{4}$ & $\begin{array}{r}13.54 \\
1.20\end{array}$ & $\begin{array}{r}14 \cdot 63 \\
2 \cdot 17\end{array}$ & $\begin{array}{r}14.46 \\
1 \cdot 70\end{array}$ & $\begin{array}{r}14.86 \\
1 \cdot 96\end{array}$ \\
\hline $\mathrm{R}_{5}$ & $\begin{array}{r}13.46 \\
1 \cdot 45\end{array}$ & $\begin{array}{r}14.70 \\
1.91\end{array}$ & $\begin{array}{r}14 \cdot 38 \\
1 \cdot 75\end{array}$ & $\begin{array}{r}14 \cdot 62 \\
2 \cdot 01\end{array}$ \\
\hline
\end{tabular}

graphically in figs. I and 2. It is apparent from the figures that in Melandrium, as in rye (Rees and Thompson, 1956), these characters are continuously distributed variables.

The results of analyses of variance within and between groups of families are shown in tables 2 and 3. It is clear from these results 
that the genetic variation between groups is considerably-and significantly-greater than that within them with regard to both characters (item 1 , tables 2 and 3). Significant differences among

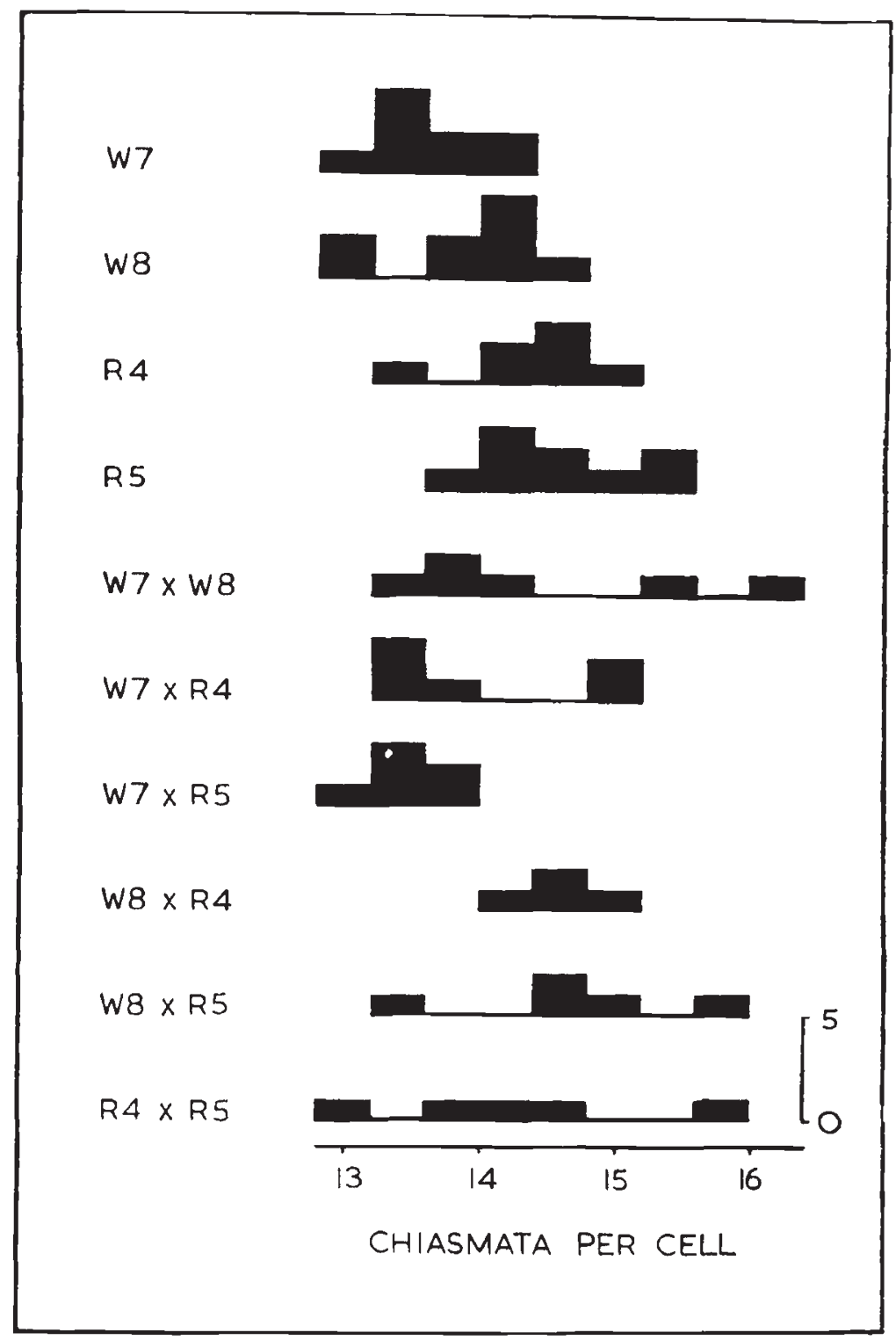

FIG. 1.-Histograms showing the distribution of the average chiasma frequency per family in the parent and $F_{1}$ groups.

Vertical scale, number of families; horizontal scale, the average chiasma frequency per family expressed as chiasmata per cell.

parents and among $F_{1}$ 's are found for each character, (item I (i) and (ii)) but neither shows any consistent heterosis (item I (iii)). There is no evidence for differences between reciprocal $F_{1}$ 's, and hence it is 
presumed that in these samples the majority of the genetic variation resides in the autosomes.

It can also be seen from the tables and figures that the average

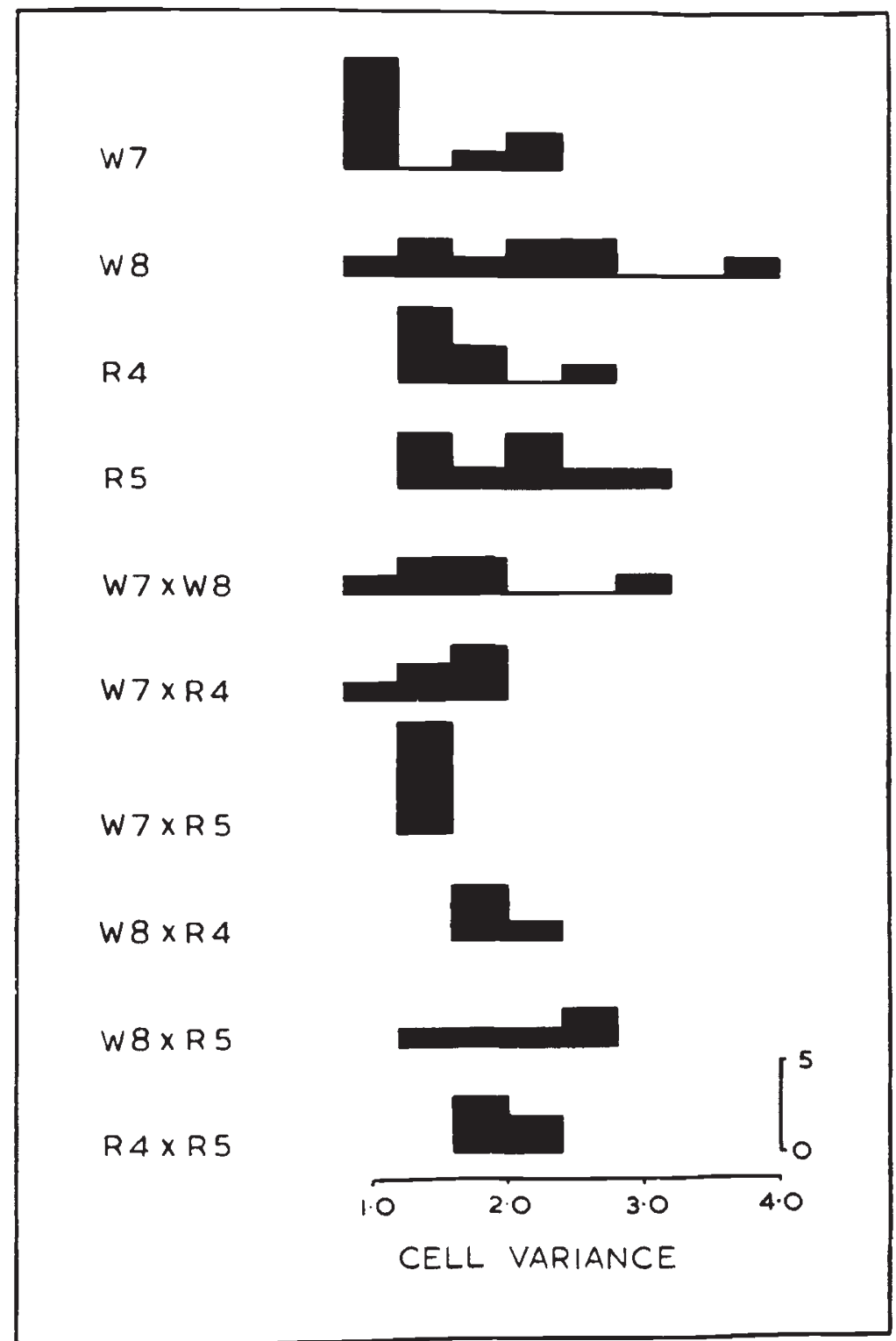

Fig. 2.-Histograms showing the distribution of the average cell variance per family in the parent and $F_{1}$ groups.

Vertical scale, number of families; horizontal scale, the average cell variance per family.

variation between families within parental groups differs considerably from that within the groups (item 3 (i) and (ii)). In one case, that of the average chiasma frequency, the variation within $F_{1}$ groups is 
the greater, while in the other case the situation is reversed. In table 4 individual $F_{1}$ variances are compared with either those of the nearer parent or with the pooled variance of both parents where these are homogeneous. For chiasma frequency three $F_{1}$ 's $(7 \times 8,7 \times 4$, $8 \times 5$ ) show significantly greater variation than their parents, one

TABLE 2

Analysis of variance of average chiasma frequency per plant

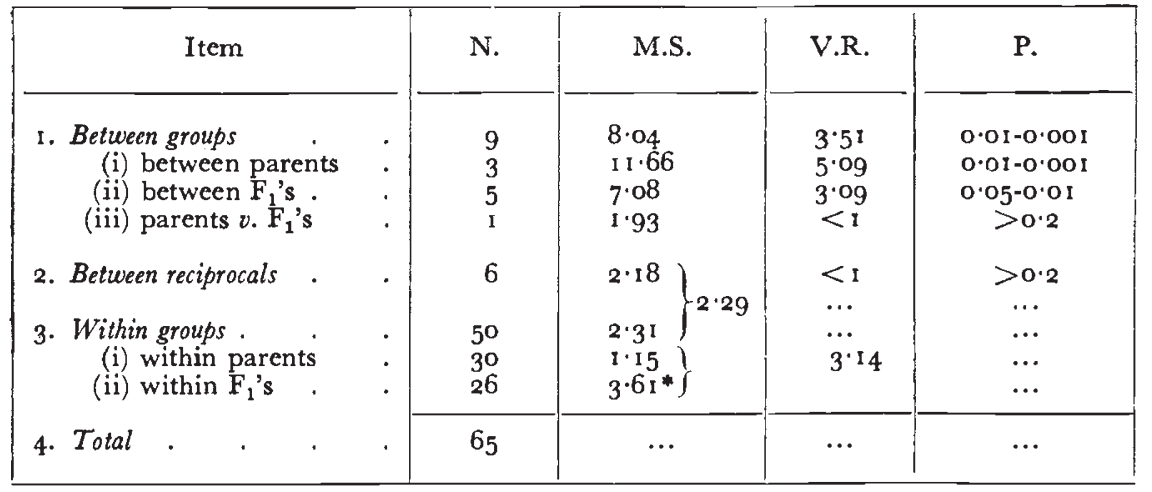

* Including reciprocals.

TABLE 3

Analysis of variance of average cell variance per plant

\begin{tabular}{|c|c|c|c|c|c|}
\hline Item & & N. & M.S. & V.R. & P. \\
\hline $\begin{array}{l}\text { I. Between groups } \\
\text { (i) between parents } \\
\text { (ii) between } F_{1} \text { 's } \\
\text { (iii) parents } v . F_{1} \text { 's }\end{array}$ & : & $\begin{array}{l}9 \\
3 \\
5 \\
1\end{array}$ & $\begin{array}{l}3 \cdot 15 \\
5 \cdot 67 \\
2 \cdot 07 \\
0 \cdot 99\end{array}$ & $\begin{array}{l}2 \cdot 27 \\
2 \cdot 92 \\
2 \cdot 78 \\
<1\end{array}$ & $\begin{array}{l}0.05-0.01 \\
0.05 \\
0.05-0.01 \\
>0.2\end{array}$ \\
\hline 2. Between reciprocals . & . & 6 & 0.56 & $<$ I & $>0.2$ \\
\hline $\begin{array}{l}\text { 3. Within groups . } \\
\text { (i) within parents } \\
\text { (ii) within } \mathrm{F}_{1} \text { 's . }\end{array}$ & : & $\begin{array}{l}50 \\
30 \\
26\end{array}$ & $\left.\begin{array}{l}\text { I.49 } \\
\text { I.94 } \\
0 \cdot 75^{*}\end{array}\right\}$ & $2 \ddot{6}$ r & $\begin{array}{l}\ldots \\
\cdots\end{array}$ \\
\hline 4. Total . & $\cdot$ & 65 & $\ldots$ & $\ldots$ & $\ldots$ \\
\hline
\end{tabular}

* Including reciprocals.

$(7 \times 5)$ significantly less, while the remainder $(8 \times 4,4 \times 5)$ are not significantly different. With the cell variance five of the six $F_{1}$ 's have smaller within group variances than their parents, but in only one case $(7 \times 5)$ is the difference significant. These disparities confirm that samples have characteristic and different arrays of genotypes. Further it is likely that they reflect the particular properties of the gene systems concerned. This will be discussed in more detail later. 
As the data form a diallel table, the method of Jinks (1954), in its generalised form (Dickinson and Jinks, I956), for such sets of data may be used to investigate the nature of the genetic variation. In this method the covariance of progeny means onto the nonrecurrent parent $(\mathrm{Wr})$ is graphically compared with the variance of progeny means $(\mathrm{Vr})$. Wr may also be compared with the covariance of progeny means onto the non-recurrent array mean ( $W^{\prime} r$ ) (Hayman, 1958). It was, of course, impossible to self the plants in the samples, and thus no estimate of $\mathrm{P}_{2}$ (Dickinson and Jinks, loc cit.) could be made. However the parents correspond to the $P_{1}$ of these authors

TABLE 4

Comparisons of the variance within $F_{1}$ groups and that within their parents; (a) with regard to average chiasma frequency, (b) with regard to the average cell variance

\begin{tabular}{|c|c|c|c|c|c|c|c|}
\hline & $F_{1}$ & $\begin{array}{l}\text { Variance of } \\
\text { parent * }\end{array}$ & $\mathrm{N}$ & $\begin{array}{c}\text { Variance } \\
\mathrm{F}_{1}\end{array}$ & $\mathrm{~N}$ & V.R. & $\mathbf{P}$ \\
\hline$(a)$ & $\begin{array}{l}7 \times 8 \\
7 \times 4 \\
7 \times 5 \\
8 \times 4 \\
8 \times 5 \\
4 \times 5\end{array}$ & $\begin{array}{l}I \cdot 157 \\
0.579 \\
I \cdot 244 \\
0.960 \\
I \cdot 624 \\
I \cdot 711\end{array}$ & $\begin{array}{r}16 \\
14 \\
16 \\
14 \\
16 \\
8\end{array}$ & $\begin{array}{l}6 \cdot 651 \\
3 \cdot 33.5 \\
0 \cdot 243 \\
0 \cdot 524 \\
6 \cdot 344 \\
3 \cdot 949\end{array}$ & $\begin{array}{l}5 \\
5 \\
5 \\
3 \\
4 \\
4\end{array}$ & $\begin{array}{c}5 \cdot 75 \\
5 \cdot 76 \\
5 \cdot 11 \\
1 \cdot 83 \\
3 \cdot 91 \\
2 \cdot 31\end{array}$ & $\begin{array}{c}0.01-0.001 \\
0.01-0.001 \\
0.05-0.01 \\
>0.2 \\
0.05-0.01 \\
0.2-0.1\end{array}$ \\
\hline$(b)$ & $\begin{array}{l}7 \times 9 \\
7 \times 4 \\
7 \times 5 \\
8 \times 4 \\
8 \times 5 \\
4 \times 5\end{array}$ & $\begin{array}{l}2 \cdot 624 \\
0 \cdot 4 \text { II } \\
1 \cdot 743 \\
0 \cdot 4 \text { II } \\
2 \cdot 604 \\
0 \cdot 4 \text { II }\end{array}$ & $\begin{array}{r}16 \\
6 \\
16 \\
6 \\
6 \\
16 \\
6\end{array}$ & $\begin{array}{l}I \cdot 589 \\
0.325 \\
0.036 \\
0.689 \\
I \cdot 753 \\
0.159\end{array}$ & $\begin{array}{l}4 \\
5 \\
5 \\
3 \\
4 \\
4\end{array}$ & $\begin{array}{r}\mathrm{x} \cdot 67 \\
\mathrm{I} \cdot 26 \\
4 \cdot 6 \mathrm{I} \\
\mathbf{1} \cdot 68 \\
1 \cdot 49 \\
2 \cdot 58\end{array}$ & $\begin{array}{l}>0.2 \\
<0.2 \\
>0.001 \\
<0.2 \\
<0.2 \\
0.2-0.1\end{array}$ \\
\hline
\end{tabular}
parent.

* Variances of parents pooled if homogeneous, otherwise the value is the nearer

and form the parental diagonal in the analyses. It may be noted that the interpretation of neither $\mathrm{Wr} / \mathrm{Vr}$ nor $\mathrm{W}^{\prime} \mathrm{r} / \mathrm{Wr}$ graphs is affected by sex linkage as long as $\mathrm{F}_{1}$ values are obtained from pooled reciprocal families (Jinks, unpublished). $\mathrm{Wr} / \mathrm{Vr}$ and $\mathrm{W}^{\prime} \mathbf{r} / \mathrm{Wr}$ graphs of the data are given in fig. 3 .

With regard to the average chiasma frequency neither the $\mathrm{Wr} / \mathrm{Vr}$ nor $W^{\prime} r / W r$ regression is significant, indicating the low heritability of this character. In view of the results of the analysis of variance (table 2) it is unlikely that the low heritability arises from a large environmental component in the variation; it is more probable that it can be ascribed to a complex genetical control of the character, perhaps involving non-allelic interaction. It is not possible, however, to test directly for the presence of non-allelic interaction in these data.

The $\mathrm{Wr} / \mathrm{Vr}$ and $\mathrm{W}^{\prime} \mathrm{r} / \mathrm{Wr}$ graphs of the cell variance data present an entirely different picture from those of the average chiasma frequency. Both the $\mathrm{Wr} / \mathrm{Vr}$ and $\mathrm{W}^{\prime} \mathrm{r} / \mathrm{Wr}$ regressions are significant $(\mathrm{P}=0.05-0.0 \mathrm{I}$ 
and $\mathrm{P}<0 \cdot 00 \mathrm{I}$ respectively), showing the high heritability of the cell variance. The slopes of these regressions are $b=+0.948 \pm 0.127$ and $b=+0.597 \pm 0.017$ respectively. Dickinson and Jinks have shown that in random mating populations with equal gene frequencies and

Average Chiasma Frequency

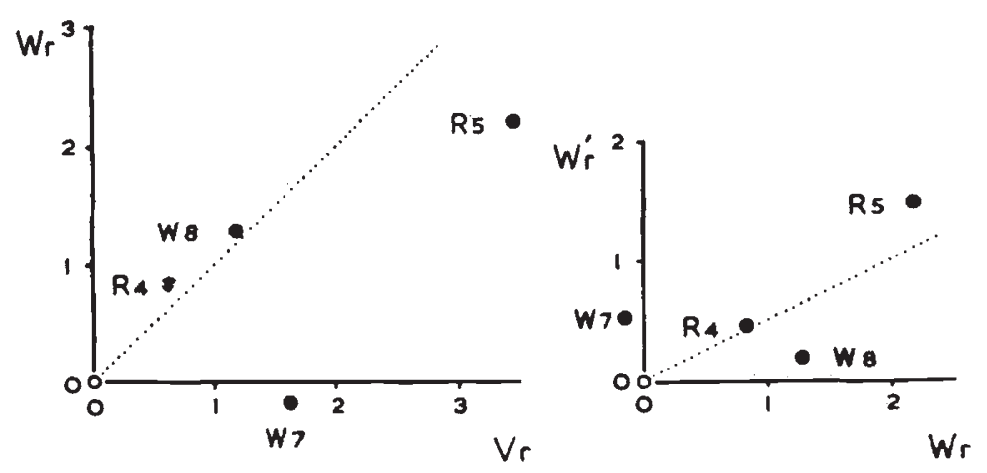

Average Cell Variance
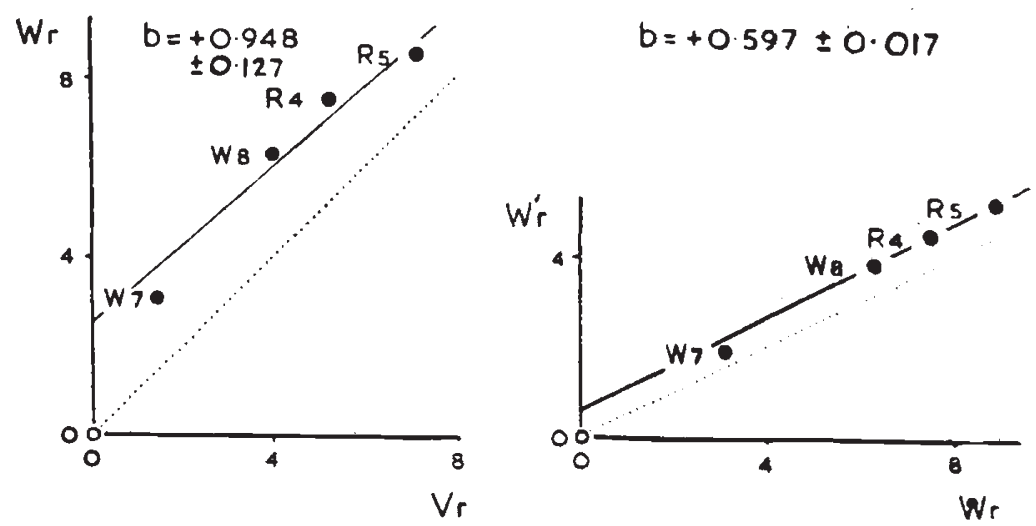

Fic. 3.- $\mathrm{Wr} / \mathrm{Vr}^{*}$ and $\mathrm{W}^{\prime} \mathrm{r} / \mathrm{Wr}$ graphs of the average chiasma frequency and the average cell variance. The broken lines passing through the origin have slopes of one and one-half in the $\mathrm{Wr} / \mathrm{Vr}$ and $\mathrm{W}^{\prime} \mathrm{r} / \mathrm{Wr}$ graplis respectively. Full details concerning the interpretation of $\mathrm{Wr} / \mathrm{Vr}$ graphs may be seen in Dickinson and Jinks (1956) and for $\mathrm{W}^{\prime} \mathrm{r} / \mathrm{Wr}$ graphs in Hayman (1958).

complete dominance, the $\mathrm{Wr} / \mathrm{Vr}$ regression has a slope of about +0.9 and passes through the origin. While the slope of the present $\mathrm{Wr} / \mathrm{Vr}$ graph is quite close to this expectation, it cuts the $\mathrm{Wr}$ axis at a point far removed from the origin. By extrapolation $\mathrm{Wr}$ has a value of $+2 \cdot 2$ when $\mathrm{Vr}=0$, a deviation which is significant at the one per cent. level. A positive intercept of this kind may arise from a high overall level of heterozygosity or from incomplete dominance (Dickinson 
and Jinks, loc cit.). Evidence is given in the following paper which suggests that the first alternative is unlikely, and it is more probably that the genes controlling the cell variance show incomplete dominance.

It would appear from the $\mathrm{Wr} / \mathrm{Vr}$ and $\mathrm{W}^{\prime} \mathrm{r} / \mathrm{Wr}$ graphs that the genetic control of the average chiasma frequency is different from that of the cell variance. In rye, Rees and Thompson (1956, 1958) have shown that although there is a tendency for the characters to be negatively correlated, they are to a considerable extent independent of one another. It can be seen from table 5 , which shows the results

TABLE 5

Analysis of variance based on the regression of the cell variance on the average chiasma frequency. Error 2 is compared with error 1 , and error 3 with error 2

\begin{tabular}{|c|c|c|c|c|}
\hline Item & N. & M.S. & V.R. & P. \\
\hline $\begin{array}{l}\text { I. Within families } \\
\text { (i) Joint regression } \\
\text { (ii) Heterogenesty of regression } \\
\text { (iii) Error 1 }\end{array}$ & $\begin{array}{r}307 \\
1 \\
62 \\
244\end{array}$ & $\begin{array}{r}58 \cdot 57 \\
1 \cdot 97 \\
0 \cdot 65\end{array}$ & $\begin{array}{c}89 \cdot 55 \\
3 \cdot 01 \\
\cdots\end{array}$ & $\begin{array}{c}<0 \cdot 00 \mathrm{I} \\
<0 \cdot 00 \mathrm{I} \\
\quad \ldots\end{array}$ \\
\hline $\begin{array}{l}\text { 2. Between families. } \\
\text { (i) Joint regression } \\
\text { (ii) Heterogenesty of regression } \\
\text { (iii) Error 2 }\end{array}$ & $\begin{array}{r}56 \\
1 \\
9 \\
46\end{array}$ & $\begin{array}{r}22 \cdot 39 \\
1 \cdot 45 \\
0 \cdot 92\end{array}$ & $\begin{array}{r}24 \cdot 42 \\
1 \cdot 58 \\
1 \cdot 40\end{array}$ & $\begin{array}{l}<0 \cdot 001 \\
0.2-0.1 \\
0.1-0.05\end{array}$ \\
\hline $\begin{array}{l}\text { 3. Between groups } \\
\text { (i) Regression } \\
\text { (ii) Error } 3\end{array}$ & $\begin{array}{l}9 \\
1 \\
8\end{array}$ & $\begin{array}{r}10 \cdot 27 \\
2.28\end{array}$ & $\begin{array}{l}4 \cdot 50 \\
2 \cdot 49\end{array}$ & $\begin{array}{c}0.08 \\
0.05-0.01\end{array}$ \\
\hline 4. Total & 372 & $\ldots$ & $\ldots$ & $\ldots$ \\
\hline
\end{tabular}

of an analysis of covariance, that while there is a significant regression of the cell variance on the average chiasma frequency within families, and between family means within groups (items I (i) and 2 (i)), the regression between group means is insignificant (item 3 (i)). The residual variation to this last item is however significant (item 3 (ii)). This is not due to curvilinearity. Further the relation between the characters varies from family to family (item I (ii)). Thus while there is, as in rye, a tendency for the two characters to be correlated within samples, they are nevertheless unrelated between them. Contrary to the results of Rees and Thompson (loc. cit.), however, the correlation is positive.

\section{DISCUSSION}

It has been shown that with regard to the average chiasma frequency and the average cell variance, the genetic variation between plants from different population samples is three and two times respectively greater than that between individuals from the same sample. In so far as these random samples adequately represent the populations from which they were drawn, it can be concluded that in a similar 
manner there is much greater genetic variation between than within the populations with respect to these two aspects of the recombination system.

Such differences between the populations appear to depend on the action of a number of genes. No evidence was found which suggested that structural rearrangements in the chromosomes were of any importance in determining the number or distribution of chiasmata, and indeed the occurrence of heterosis in some of the hybrids, both between and within species, would militate against such a view.

The genetic differences between the populations have, no doubt, been brought about by the action of natural selection, and in so far as the number and distribution of chiasmata influence the amount and pattern of recombination they represent the adaption of the populations to their differing environmental and genetic backgrounds. Selection cannot discriminate between individuals showing differences in these characters, for except in the limiting case where the number and distribution of chiasmata is such as to produce appreciable failure of chromosome pairing at metaphase, the variation does not affect the external phenotype. Selection can only act on the progeny of the individuals over many generations. It is of the type that has been called metaselection by Waddington (1957). The effectiveness of metaselection is well illustrated by the data.

Population differences of these kinds may be compared with those involving varying frequencies of chromosome structural rearrangements found in Drosophila (Dobzhansky and Epling, r944; Dobzhansky, I939, r948; Spiess, 1950; Stalker and Carson, r948; Carson, I955), in Grasshoppers (White, 1956, 1957), in Peonia (Walters, 1942), in Clarkia (Hakansson, I942 ; Hiorth, I942 ; Mooring, I958) and in Periplaneta (John and Lewis, 1958). As observed previously, no evidence of segmental hybridity of these types was found in Melandrium and the two species therefore appear to have "open " recombination systems in the terminology of Carson (I957).

Natural selection cannot, within certain limits, be expected to discriminate between different methods of controlling the amount of recombination within populations. At least from the short term view it is immaterial whether the amount of recombination is regulated by the polygenic control of the number and position of chiasmata or by a system of chromosome structural rearrangements. From the long term point of view, however, these two methods may have different consequences and it is probable that polygenic control of the number of chiasmata is in general the more flexible method (cf. " The ideal mode of reproduction," Darlington, 1956b).

The evolutionary importance of the chiasma frequency and cell variance can, of course, only be assessed in relation to all the other aspects of the recombination system. Despite the differences between the populations, in all cases the chiasma frequency is close to the 
minimum of one per bivalent required for full fertility. Further the number of chromosomes in Melandrium is quite low and the chiasmata are highly localised (see plate). Finally the plants appear to inbreed to a certain, possibly considerable, extent (Lawrence, unpub.). Taking all these factors into account it is clear that the recombination system in Melandrium is organised to permit relatively little recombination. Such a situation presumably indicates that the populations inhabit relatively stable environments. Despite the emphasis on reduced recombination, the two species have not at the present entirely dispensed with sexual reproduction. No doubt only that type of recombination system which potentially is capable of being adjusted to give increased recombination has survived (Darlington, I 939).

The nature of the polygenic differences between the populations with regard to the two characters was investigated by means of the method of Jinks (1954) in its generalised form (Dickinson and Jinks, I956). The average chiasma frequency was found to be a character of low heritability, perhaps due to the presence of non-allelic interaction and also possibly heterozygosity. Heterozygosity alone is inadequate to explain the low heritability since the regression of $W^{\prime} r$ on Wr was not significant and in general this regression, unlike that of $\mathrm{Wr}$ on $\mathrm{Vr}$, is insensitive to the disturbing influence of heterozygosity. Further support for the suggestion that the control of chiasma frequency in these samples is complex is derived from the changing relations of the variances between families within $F_{1}$ groups to those within parental groups. In some cases the $F_{1}$ variance was greater than that of either parent, in others it equalled them, while in one case both parental variances exceeded the $F_{1}$ variance. It is possible that the relative sizes of the variances within the groups of $F_{1}$ 's and parents are merely a result of differences in the developmental stability (Mather, I953) of these genotypes. It is, however, more likely that they arise from the particular action and distribution of genes controlling chiasma frequency. A greater variation between interpopulation, than intra-population, families has been predicted by Mather (1943). Following the argument of Fisher (1930) it was pointed out (víather, I943, I960; Breese and Mather, I960) that if a character was subject to stabilising selection, as presumably is the case with chiasma frequency, dominance in the gene system would tend to be ambidirectional. In each population, therefore, much of the dominance variation would remain hidden. However, as it is likely that there is dispersion of dominant genes between various populations, the hidden dominance variation will be revealed by crossing. This appears to have occurred in crosses $7 \times 8,7 \times 4,8 \times 5$, and $4 \times 5$. It is, however, difficult to accommodate the result from cross $7 \times 5$ in this scheme, for variation is concealed rather than exhibited in this inter-population hybrid. Viewing the data as a whole, some form of non-allelic interaction appears also to be indicated by these differing relations of the variances. Results from sets of 
diallel crosses (Jinks, I952) show that variation may be concealed by the presence of epistasis.

Although the presence of genic interaction cannot be proved in the present data, it is not unreasonable to invoke its action to explain the results. The $\mathrm{Wr} / \mathrm{Vr}$ and $\mathrm{W}^{\prime} \mathrm{r} / \mathrm{Wr}$ regressions require a similar explanation, and further, interaction is a characteristic of the control of chiasma frequency in rye (Rees and Thompson, I956). Moreover the selective value of chiasma frequency shows a sharp discontinuity at one chiasmata per bivalent. The genetic architecture of the character (Mather, I96o) would therefore be expected to allow variation above, but not below, this value in normal population plant, a situation favouring interaction. It is significant that the cross $7 \times 5$ has the lowest mean chiasma frequency of all hybrids.

In marked contrast to chiasma frequency, the cell variance shows high heritability and incomplete dominance. The contrast suggests that the two characters are, at least in part, genetically independent of one another. This conclusion was confirmed by covariance analysis. Between parent and $F_{1}$ groups the cell variance and the chiasma frequency were found to be independent. Within groups, however, small positive correlations were found. These appear to arise from a lower limit to variation at twelve chiasmata per cell. Univalent pairs were rare in the material, less than 0.03 per cell on the average, and all genotypes were uniform in this respect. Fifteen per cent. of the univalent pairs involved the sex chromosomes, a significant deviation from the expected $8 \frac{1}{3}$ per cent. ( $\left.P=0.0 \mathrm{I}-0.00 \mathrm{I}\right)$ which is probably due to the shortness of the pairing segment. Plants with low chiasma frequencies are likely, in the presence of a lower limit, to have a smaller cell variance than those with a higher chiasma frequency.

The independent adjustment among the various populations of these two components of the recombination system was no doubt brought about by natural selection. Such adjustment illustrates the complexity and precision of the mechanism which controls the quality and quantity of heritable variation exposed to the action of natural selection.

From the genetic point of view the cell variance is a component of the recombination system; from the phenotypic point of view however it is a measure of developmental stability (Mather, I953). It is clear from the results that neither stability nor lability has of itself selective value, but that the amount of variation is an adaption to a particular environment (Mather, I953 ; Thoday, I953).

\section{SUMMARY}

Genetic differences with respect to (i) the average chiasma frequency per male plant, and (ii) the variation between pollen mother cells in chiasma frequency have been found between samples of plants from two populations of Melandrium album and two of $M$. 
rubrum. In so far as the random samples adequately represent the populations from which they were drawn, it is concluded that the differences between the populations have been brought about by natural selection. The average chiasma frequency and the cell variance were independently adjusted by selection in the different populations. The genetic differences between the populations depend on the action of many genes. No evidence that structural differences between chromosomes from the various populations were of importance in determining the number of chiasmata could be found. The recombination system in Melandrium appears to be regulated in such a manner as to permit relatively little recombination.

Acknowledgments.-I am greatly indebted to Prof. K. Mather, D.Sc., F.R.S., and to $\mathrm{Dr} \mathrm{H}$. Rees for advice and criticism throughout the course of this work. I would also like to thank $\mathrm{Dr} \mathrm{J}$. L. Jinks for much useful discussion.

\section{REFERENCES}

BREESE, L. 196o. Selection for differing degrees of out-breeding. Annals of Botany (in press).

BREESE, L., AND MATHER, K. 1960. The organisation of polygenic activity within a chromosome in Drosophila. II. Viability. Heredity, 14, 375-399.

CARson, H. L. 1956. Marginal homozygosity for gene arrangement in Drosophila robusta. Science, 123, 630-631.

Carson, H. L. 1957. The species as a field for recombination. The Species Problem, ed. E. Mayr.

DARLington, C. D. 1932. The control of the chromosomes by the genotype and its bearing on some evolutionary problems. Ann. Nat., 66, 25-5I.

DARLington, C. D. 1939. Evolution of Genetic Systems. Ist. Ed. Cambridge U.P.

DARLington, C. D. I956a. Natural populations and the breakdown of classical genetics. Proc. Roy. Soc. B, 145, 350-364.

Darlington, C. D. 1956b. Chromosome Botany. Allen and Unwin.

DARLington, C. D. 1958. Evolution of Genetic Systems. 2nd Edition. Cambridge U.P. Dickinson, A. G., AND Jinks, J. L. 1956. A generalised analysis of diallel crosses. Genetics, 4I, 65-78.

Dobzhansky, Th. 1939. Microgeographic variation in Drosophila pseudoobscura. Proc. Nat. Acad. Sci. Wash., 25, 3 I I-314.

DoBzhansky, тн. 1948. Chromosomal variation in populations of Drosophila pseudoobscura which inhabit Northern Mexico. Ann. Nat., 82, 97-106

DoBzhansky, TH., AND EPLING, c. 1944. Contributions to the genetics, taxonomy and ecology of Drosophila pseudoobscura and its relatives. Publ. Carneg. Inst., 554 .

FISHER, R. 1930. The Genetical Theory of Natural Selection. Oxford U.P.

Goldschmidt, R. 1940. The Material Basis of Evolution. Yale U.P.

hakANsson, A. 1942. Zytologische Studien an Rassen und Rassenbastarden von Godetia Whitneyi und Verwandten Arten. Lunds. Univ. Arsskrift (Andra. Med.) NF.2. $3^{8}(5)$, I -69 .

hayman, в. I. 1958. The theory and analysis of diallel crosses II. Genetics, 43, $63-85$.

HIORTH, G. 1942. Zur Genetik und Systematik de amoena-Gruppe der Galtung Godetia. Zeit Ind. Abst. Vererb., 8o, 289-349.

JiNks, J. L. 1952. Ph.D. Thesis, University of Birmingham. 


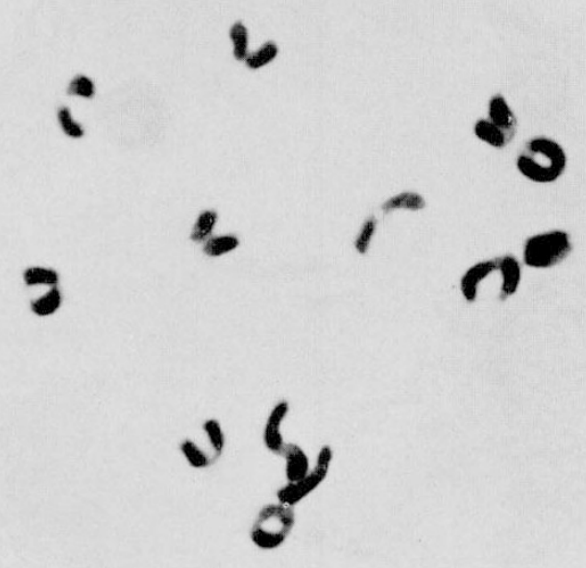

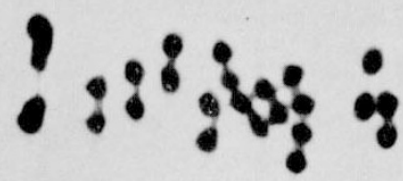

Top.-Late diplotene in a pmc. of $M$. album. Note that the chiasmata are localiscd at the ends of the chromosomes.

Bottom.-Metaphase I in a pmc. of M. album. All bivalents have one terminal chiasmata. 
JINKs, J. L. 1954. The analysis of continuous variation in a diallel cross of Nicotiana rustica varieties. Genetics, 39, 767-788.

JOHN, B., AND LEWIS, K. R. 1958. Studies on Periplaneta americana. III. Selection for heterozygosity. Heredity, 12, $185-197$.

LAWRENCE, C. W. 1963. Genetical studies on wild populations of Melandrium. II. Flowering time and plant weight.

LEWIS, D. 1954. Comparative incompatibility in angiosperms and fungi. Ad. Genetics, 6, 235-285.

MAther, K. 1943. Polygenic inheritance and natural selection. Biol. Revs., I8, $32-64$.

mather, к. 1949. Biometrical Genetics. Methuen.

MATHER, K. 1953. Genetical control of stability in development. Heredity, 7, 297-336.

mather, K. 1960. Evolution of polygenic systems. Evoluzione e Genetica, 47, $131-152$.

MOORING, J. 1958. A cytogenetic study of Clarkia unguiculata. I. Translocations. Am. Jour. Bot., 45, 233-242.

RFES, H. 1961. Genotype control of chromosome form and behaviour. Biol. Revs., 27, 288-318.

REES, H., AND THOMPSON, B. 1956. Genotypic control of chromosome behaviour in rye. III. Chiasma frequency in homozygotes and heterozygotes. Heredity, 1o, 409-424.

REES, H., AND THOMPSON, B. 1958. Genotypic Control of chromosome behaviour in rye. $\mathrm{V}$. The distribution pattern of chiasmata between pollen other cells. Heredity, 12, $101-112$.

SPIESS, E. 1950. Experimental populations of Drosophila persimilis from an altitudinal transect of the Sierra Nevada. Evolution, 4, 14-33.

STALKER, H. D., AND CARSON, ir. L. 1948. An altitudinal transect of Drosophila robusta Sturtevant. Evolution, 2, 295-305.

THODAY, J. M. 1953. The components of fitness. S.E.B. Symp. Vol. VII. Evolution, 96-II3.

Waddington, C. H. 1957. The Strategy of the Genes. Allen and Unwin.

n.Alters, J. L. 1942. Distribution of structural hybrids in Paeonia Californica. Am. Four. Bot., 29, $270-275$.

WHiтE, м. J. 1956. Adaptive chromosomal polymorphism in an Australian grasshopper. Evolution, 10, 298-313.

WHite, M. J. 1957a. Cytogenetics of the grasshopper Moraba scurra. I. Meiosis of interracial and interpopulation hybrids. Aust. 7. Zoo., 5, 285-304.

WHite, м. J. 1957b. Cytogenetics of the grasshopper Moraba scurra. II. Heterotic systems and their interaction. Aust. F. Zoo., 5, 305-337. 